\title{
BRITISH COLONIAL TERRITORIES
}

"T THE Colonial Territories, 1958-59"* provides the usual convenient compendium of information to such further publications as "Colonial Research" dealing with the British Commonwealth and itself includes a 24-page chapter dealing with "Research and Surveys", to which grants totalling $\mathfrak{E} 800,824$ were made from Colonial Development and Welfare Funds for a further 134 research schemes. The recommendations of the meeting at Lagos in January 1958 for the future organization of research in West Africa have now been accepted by the Governments of Ghana, Gambia, Nigeria and Sierra Leone, and the West African Research Office came formally into being on April 1, 1959. The Government of Ghana has now abandoned its intention of taking over the West African Cocoa Research Institute, which will accordingly continue as a fully inter-territorial research body. The Commission for Technical Co-operation in Africa South of the Sahara has decided to transfer the headquarters of the joint secretariat from London to Lagos.

Approved technical assistance projects in the British-dependent territories in 1959 under the United Nations Expanded Programme of Technical Assistance (to which the United Kingdom Government at present contributes the sterling equivalent of $2,240,000$ dollars a year) amounted to $1,062,750$ dollars. Expenditure from Colonial Development and Welfare Funds was $£ 17.8$ million and the Vote for Colonial Services included $£ 24,223,000$ as financial aid to Colonial Governments. Exports (excluding Northern Rhodesia and Nyasaland) fell by $£ 46$ million and imports by nearly $£ 80$ million, including about $£ 35$ million in Hong Kong and Singapore and nearly $£ 20$ million in East Africa. Capital formation in 1958 remained at about the same value as in 1957 .

Among some other points which may be mentioned are the rapid expansion of educational facilities, although the provision of new school places and additional teachers remains the over-riding problem

* Colonial Office. The Colonial Territories, 1958-1959. Pp. $x x v+\frac{1}{2}$ 199. in most territories. In October 1958, the two universities and three university colleges in Central Africa. had 3,783 students, compared with 3,400 the previous year, and there were 1,615 students at the University of Malaya, which serves Singapore as well as the independent Federation of Malaya. Capital sums provided under the Colonial Development and Welfare Act for university institutions are now almost completely committed, and a main financial problem is now to provide the required inerease in accommodation for residence and teaching. The Singapore Polytechnic opened in November 1958 with 385 fulltime, 506 day-release and 2,005 evening students, and a second new technical college in Jamaica opened in March 1958 with 60 students. In Jamaica, 11,000 extra primary places were provided out of the 16,000 required, and in Uganda the number of African pupils in aided secondary schools has risen from 5,517 in 1951 to 17,306 in 1958 .

Attachments of American teachers to institutions in British Colonial territories continued under the Fulbright Agreement, and the Overseas Visual Aids Centre was officially opened in London in February. Departments of health generally were able to meet increasing demands on all services while maintaining a fair balance between curative and preventive work. Mass campaigns and surveys or pilot projects preceding them have been used extensively to combat endemic diseases, but although the incidence of malaria and yaws has been dramatically reduced in this way, tuberculosis remains a serious problem. Progressive improvement in water supplies in rural and urban areas has considerably assisted the control of water-borne diseases. The Institute of Health in Singapore was completed in 1958 with assistance of a grant of 1,500,000 dollars from Colonial Development and Welfare Funds, and during 1958, 144 medical students and 5 dental students from the Colonial territories were placed by the Colonial Office in teaching schools in the United Kingdom and the Irish Republic. Several overseas governments are now contributing to the Applied Nutrition Unit at the London School of Hygiene and Tropical Medicine.

\section{GERM-FREE VERTEBRATES: PRESENT STATUS}

$\mathrm{I}$ a recent publication by the New York Academy of Sciences résumés are given of a series of papers delivered at a conference held by the Academy during May 1958*. It is divided into five parts : the first and second are concerned with instrumentation and with rearing of germ-free vertebrates; the third is concerned with the biological characteristics of germ-free animals; the fourth and fifth describe ways in which germ-free animals have been successfully used as a tool to solve otherwise intractable problems and discusses future possibilities in this direction.

It has taken thirty years of technical development to produce germ-free animals of most laboratory species and thereby refute the opinion of Pasteur * Annals of the New York Academy of Sciences. Vol. 78, Article $1:$ Germfree Vertebrates: Present Status By James A. Reyniers and 30 other authors. Pp. $1-400$.
of Sciences, 1959.) 5 dollars. that germ-free animals would not survive. Although the methods adopted are subject to continuous improvement, simplification and standardization, they remain expensive and complex. Nevertheless, the time has come when germ-free animals are produced on a limited scale for practical research projects and, since the maintenance of the germ-free state over a limited time is much simpler than the production of germ-free animals, a plea is made for wider support for centres to produce and distribute them. Study of the physiology and nutritional requirements of germ-free animals is a necessary preliminary to their use in research. In this connexion, it is noted that their lymphoid tissue is immature compared with that of conventional animals. Plasma cells are present in small numbers and the amount of serum $\gamma$-globulin is much reduced. 